DOI https://doi.org/10.30525/978-9934-26-114-5-27

\title{
НАПРЯМИ ДІЯЛЬНОСТІ КЛУБНИХ ОБ'ЄДНАНЬ ПЕДАГОГІЧНИХ ЗВО УКРАЇНИ
}

\author{
Чубукіна О. М. \\ аспірантка кафедри освітологї та інноваційної педагогіки \\ Харківський національний педагогічний університет \\ імені Г. С. Сковороди \\ м. Харків, Украӥна
}

В світі інновацій та новітніх технологій сучасний учитель повинен володіти важливими компетенціями для професійного росту. По-перше, бути активним, гнучким, уміти адаптуватися в будь-якій ситуації. По-друге, бути націленим на розвиток, постійно вдосконалюватися, знаходити цікаві підходи і проявляти креативність. По третє, учитель повинен розділяти та втілювати в своїй практиці принципи гуманної педагогіки.

Важливу роль у професійному та творчому розвитку майбутніх учителів відіграють клубні об'єднання педагогічних ЗВО. Клубні об'єднання - це добровільні формування соціальної активності, які сприяють вихованню, розвитку та реалізації їх учасників. Створюючи необхідні умови, клубні об'єднання (студентські клуби, молодіжні центри, студії дозвілля, волонтерські загони, наукові гуртки, гуртки художньої самодіяльності тощо) $є$ для студентської молоді специфічним середовищем, важливим як для творчого розвитку, соціалізації, становлення життєвого досвіду, так і для розвитку лідерських якостей, підвищення рівня самооцінки, поліпшення міжособистісних відносин у колективі однолітків.

Система організації діяльності клубних об'єднань забезпечується комплексністю, тісним взаємозв'язком цілеспрямованих виховних впливів 3 самовихованням і самовдосконаленням студентів, педагогічно виправданою вимогливістю до учасників гуртків, з гуманізмом, повагою до особистості кожного.

Велике значення відіграє інтеграція формальної і неформальної взаємодії з викладачами, керівниками гуртків та однолітками. У сфері формальних i неформальних відносин розгортається співтворчість учасників позааудиторної роботи, орієнтована на формування у майбутніх учителів інтересу до пізнавальної та творчої діяльності. Викладачі та керівники гуртків стимулюють у студентської молоді 
інтерес до інтелектуального, морального й духовного розвитку та самореалізації.

У позааудиторній роботі розвиваються емоційні потенціали здобувачів вищої освіти, що забезпечує їх значний вплив на однолітків. Нерідко студент, який бере участь у наукових або творчих гуртках стає прикладом для однокурсників і своїми досягненнями стимулює у них інтерес до даного процесу.

Організація діяльності клубних об'єднань надає студентам широку палітру взаємодії з керівниками гуртків та однолітками, де відбувається активне спілкування, а також можливість сумлінного вибору напрямів занять. Напрями формуються відповідно до потреб та інтересів здобувачів вищої освіти.

Студентські клуби, молодіжні центри(як приклад Молодіжний центр «START» Уманського державного педагогічного університету імені Павла Тичини, Молодіжний центр «\#StudHub» Криворізького державного педагогічного університету) мають широкий спектр напрямів діяльності: навчально-науковий - розвиток самоврядування через неформальну освіту, проведення семінарів-тренінгів, зустрічей щодо різних аспектів розвитку молодіжного руху; менторський підтримка та супровід цікавих молодіжних проектів; інформаційноконсультаційний - надання інформаційної, методичної та консультативної допомоги молоді; сприяння залученню молоді до участі в міжнародних молодіжних, наукових заходах; проектний - підтримка проектів органів студентського самоврядування, ініціатив молоді, активна взаємодія органів влади та молоді на місцевому рівні шляхом залучення до вироблення стратегій, розробки програм, заходів та проектів; дозвіллєвий - організація змістовного дозвілля молоді, забезпечення розвитку молоді, сприяння відродженню духовності, всебічному розвитку і самореалізації студентської молоді в різних сферах суспільного життя, розкриття іiі потенціалу, захисту інтересів і прав, сприяння соціальному становленню.

Основними напрямами діяльності студій дозвілля як різновида клубних об'єднань є: організація конкурсів, фестивалів, виставок, екскурсій, спортивно-оздоровчих заходів (створення культурних традицій та формування корпоративного духу, залучення студентської молоді до спортивно-оздоровчих заходів, підвищення рівня вмотивованості участі студентів, ініціативи, наполегливості).

Клубні об'єднання, що згуртовують однодумців, які займаються активно волонтерським рухом, наприклад гурток «ASEZ-KУМ» Національного педагогічного університету імені М. П. Драгоманова, волонтерський загін «Злагода» Харківського національного 
педагогічного університету імені Г. С. Сковороди, волонтерський загін «Акорд» Полтавського національного педагогічного університету імені В. Г. Короленка, допомагають долати проблеми у сферах соціального захисту, охорони навколишнього середовища, правозахисної діяльності, збереження культурних цінностей та їх охорони, а також опікуються вихованцями дитячих будинків і будинків-інтернатів, допомагають постраждалим унаслідок АТО. Студенти-волонтери проводять різноманітні заходи, такі як семінари, форуми та надають волонтерські послуги.

Пріоритетними напрямами наукових гуртків у педагогічних 3ВО України, як різновидів клубних об'єднань є: проведення, підтримка i координація наукових досліджень; налагодження співробітництва iз вченими і науковими організаціями; організація спільних наукових проектів; проведення конференцій і семінарів; збір і поширення аналітичної інформації; обмін досвідом з організації та проведення наукової роботи студентів на всіх курсах серед членів інших гуртків; співпраця із студентськими науковими організаціями. Робота студентів у таких гуртках сприяє розвитку в них творчого мислення та наукової самостійності, поглибленню і закріпленню одержаних у процесі навчання компетенцій.

У проведенні факультетських, університетських i міських культурно-масових заходів активну участь беруть гуртки художньої самодіяльності. Свій творчий потенціал майбутні вчителі розкривають у вокальних, хореографічних, театральних, літературних і спортивних колективах.

Отже, проведення та координація наукових досліджень, організація спільних наукових проектів, інформаційно-консультаційна допомога, організація змістовного дозвілля, спортивно-оздоровчі та творчі заходи, волонтерський рух - ці та інші провідні напрями діяльності клубних об'єднань, що створюються й активно діють при педагогічних ЗВО України, сприяють удосконаленню професійних компетенцій майбутніх учителів, їхньому саморозвитку та самореалізації.

\section{Література:}

1. Волонтерський рух у Харківському національному педагогічному університеті імені Г.С. Сковороди URL: http://hnpu.edu.ua/en/ volonterskyy-ruh-u-harkivskomu-nacionalnomu-pedagogichnomuuniversyteti-imeni-gs-skovorody (дата звернення: 09.07.2021)

2. Криворізький державний педагогічний університет // Вікіпедія: вільна енциклопедія. URL: https://uk.wikipedia.org/wiki Криворізький_ державний_педагогічний_університет (дата звернення: 10.07.2021) 
3. Молодіжний центр «START» Уманського державного педагогічного університету імені Павла Тичини URL: https://youthcenters.net.ua/ molodigniy-tsentr-start/ (дата звернення: 10.07.2021)

4. Національний педагогічний університет імені М. П. Драгоманова URL: https://npu.edu.ua/novyny/podii/zahalnuniversytetski/studentyvolontery (дата звернення: 08.07.2021)

5. Університетський волонтерський загін «АКОРД» переміг у міському конкурсі «Волонтер року» URL: http://pnpu.edu.ua/news/ universytetsjkyj-volontersjkyj-zaghin-akord-peremigh-u-misjkomukonkursi-volonter-roku.html (дата звернення: 10.07.2021)

DOI https://doi.org/10.30525/978-9934-26-114-5-28

\title{
МОРАЛЬНІ ЗАДАЧІ ЯК ЗАСІБ ФОРМУВАННЯ В УЧНІВ ПІДЛІТКОВОГО ВІКУ ЦІННІСНОГО СТАВЛЕННЯ ДО ПРИРОДИ
}

\author{
Юркова Т. Ф. \\ доиент кафедри педагогіки, психології й освітнього менеджменту \\ імені проф. С. Петухова \\ Херсонський державний університет \\ м. Херсон, Украӥна
}

Сучасна педагогічна наука презентує досить об’ємну класифікацію методів виховного впливу, ефективне використання яких дає змогу будувати процес формування в підлітків ціннісного ставлення до природи на принципі поступового посилення самостійного творчого початку, орієнтувати їх на кращі зразки життєдіяльності в природі.

Стосовно проблеми нашого дослідження актуальними $\epsilon$ висновки I. Беха [1], І. Білецької [2] та С. Шмалєй [6] щодо плідності використання моральних задач у процесі ціннісного освоєння дійсності. Результативність звернення до цих задач як засобу формування ціннісного ставлення до природи пояснюється тим, що екологічні задачі внаслідок свого етичного спрямування слід розглядати як один із основних різновидів моральних задач, що й дає підставу для активного їх використання в процесі формування в підлітків ціннісного ставлення до природи в освітньо-виховному процесі загальноосвітньої школи.

Ефективність застосування задач І.Білецька вбачає, по-перше, у тому, що вони виникають в реальній життєвій практиці дитини, як 